\title{
Evaluation of Conilon coffee productivity intercropped with Ambarella (Spondias dulcis Parkinson)
}

\author{
Eduardo Ferreira Sales ${ }^{1}$, Adriana Baldi ${ }^{1}$, Juan P. Alvez ${ }^{2}$
}

\author{
'Instituto Capixaba de Pesquisa Assistência Técnica e Extensão Rural/INCAPER, Linhares, Espírito Santo, Brasil \\ ${ }^{2}$ University of Vermont, Center for Sustainable Agriculture, Burlington, VT, U.S.A. \\ Contact authors: edufsales@incaper.es.gov.br, adriana-baldi@hotmail.com, jalvez@uvm.edu \\ Received in September 16, 2019 and approved in March 10, 2020
}

\begin{abstract}
The State of Espirito Santo (Brazil) has $9.4 \%$ of its area cultivated in full sun, monocrop coffee. Coffee has a great importance for the State and a dependence on just one product can make farmers vulnerable to price fluctuations. Integrating coffee (Coffea canephora Pierre ex Froehner) intercropped with Ambarella (Spondias dulcis Parkinson) offers environmental benefits and an extra financial combination through the commercialization of Ambarella fruits. The goal of this study was to verify the effects of the distance and orientation (East-West versus North-South) between Ambarella on coffee crop yield. We assessed two different coffee crops spaced $(3 \times 1.5) \mathrm{m}$. Both were intercropped with Ambarella spaced (15 x 7.5$) \mathrm{m}$. The average coffee productivity varied from $(2,177$ to 7,346$) \mathrm{kg}$ plant ${ }^{-1}$. The lowest productivity was measured in the North-South orientation, during 2016 , and the highest in the East-West orientation during 2017. Our findings also indicate that regardless of planting distance, Ambarella did not significantly affected coffee productivity demonstrating that it can be a promising fruit tree to intercrop with Conilon coffee.
\end{abstract}

Key words: Agroforestry; coffea canephora; sustainability.

\section{INTRODUCTION}

The State of Espírito Santo is the highest Conilon coffee (Coffea canephora Pierre ex Froehner) producer in Brazil, responsible for $55.2 \%$ of the production in 2017 (Compania Nacional de Abastecimento - CONAB 2018). Family farm coffee production contributes to employment and income, especially at harvest time. Favorable temperature and topography contributes Northern Espirito Santo ideal conditions for Conilon coffee production where coffee mono cropping dominates (DaMatta 2004; DaMatta et al. 2017; Coelho et al. 2010; Iwata et al. 2012; Teixeira et al. 2014).

The rapid expansion in coffee agroecosystem caused overproduction and the crisis in the coffee market. However, this situation opens a window of opportunity to explore the potential for sustainable coffee as a way to improve the economic circumstance of small producers in Latin America (Perfecto et al. 2005).

Agroecological approaches suggest agroforestry systems as an important transitioning tool for production systems (Gliessman 2001; Cardoso et al. 2013). Some coffee producers plant trees into their crops seeking other benefits, because once correctly planned, trees can effectively help reduce adverse effect caused by winds, favor soil health and helping diversify farm income (DaMatta et al. 2017; Coelho et al. 2010).

The Ambarella tree (Spondias dulcis Parkinson) belongs to the Anacardiaceae family. This fruit originates from the Polynesian Islands, but was adapted to the Brazilian Cerrado because it has characteristics that represent the biome, being then popularly known as a fruit of the Cerrado, from which originate several by products (Ferreira and Pinto 2017; Silva et al. 2014). Ambarella is grown in domestic orchards, mainly in the North and Northeast of Brazil. The fruits are ellipsoid, drupe type, with seeds with rigid and spinescent fibers that partially dip into the pulp. This, in turn, is juicy, bittersweet and strongly aromatic, being much appreciated in natura (Lorenzi et al. 2006).

Since 2010 in Boa Esperança - NE of Espirito Santo, Brazil, a farmer has integrated Conilon coffee with Ambarella (Spondias dulcis Parkinson) in 3.48 ha of land. This farmer studied at Agricola Family School (Escola Família Agrícola). He had also taught at the Integrated Center for Rural Education (CIER) in Boa Esperança. When this farmer selected to integrate Ambarella and Coffee, he already knew about the individual characteristics of the specie and that its attributes could made them compatible with coffee plants. Once established, he manifested he was satisfied with how Ambarella performed when integrated with coffee, mainly due to its canopy morphology, which moderately shades coffee plants without considerably compromising its production (Sales et al. 2015). During a field day in 2013, the Capixaba Institute of Technical Assistance and Rural Extension, (INCAPER), proposed to monitor and measure the effects of two integrated systems between Ambarella and Coffee (Dia de Campo 2015).

In a different three 3year study, also in the State of Espirito Santo, it was demonstrated that Ambarella could be an effective companion to Conilon coffee, which produced higher yields with lower defoliation rates when shaded by Ambarella 
in comparisson with Boleira Trees (Joannesia princeps Vell.) (Souza et al. 2005). However, there is still missing information about adequate spacing for combining Ambarella with Conilon coffee. The goal of this research was to evaluate the influence of the distance between Ambarella and Conilon coffee in crops planted in orientations East-West versus North-South.

\section{MATERIAL AND METHODS}

This research was performed from 2014 to 2017, with two Conilon coffee crops (Coffea canephora Pierre ex A. Froehner), in the Town of Boa Esperanca, State of Espirito Santo (18 29'37'S, 40²3'02"W). Coffee plants were spaced $(3.0 \times 1.5) \mathrm{m}$ and both coffee crops were intercropped with Ambarella (Spondias dulcis Parkinson) in spaces (15 x 7.5) m. The difference between these two crops resides in its orientation and solar irradiation. The crop oriented E-W is 2.74 ha and the N-S is 0.74 ha. The climate in the region is tropical with average temperature of $24.1{ }^{\circ} \mathrm{C}$. The average precipitation is $1,069 \mathrm{~mm} \mathrm{yr}^{-1}$ with rains concentrated from November through March, during the summer months (Nóbrega et al. 2008). The total precipitation in the area of study, during 2013, 2014, 2015 and 2016 varied, ranging from 1,425 mm, 1,096 mm, $609 \mathrm{~mm}$ and $1,038 \mathrm{~mm}$, respectively (Instituto Capixaba de Pesquisa Assistência Técnica e Extensão Rural - INCAPER 2017). According to these data, uneven precipitation fluctuated from $3.5 \mathrm{~mm}$ in February of 2013 to $505.6 \mathrm{~mm}$ in December 2015, after facing drought from previous months, with great irregularity. Soils in the study site were Red-yellow Lato soils, (Latossolo Vermelho-Amarelo) (Empresa Brasileira de Pesquisa
- EMBRAPA 2013). Conilon coffee seedlings were planted in 2008 from three strands of $12 \mathrm{~V}$ clone -Vitoria INCAPER 8142 variety-, plus a pollination of G35 from Verdebras. The Ambarella was established in 2010. Soils were corrected using lime via base saturation until it reached $60 \%$ (Prezotti et al. 2017). Fertilization was based on soil analyses results with three-100 g of 20-05-20 applications, plus micronutrients. We utilized precision sprinkler irrigation according with moisture demand. Ambarella trees were pruned at $2 \mathrm{~m}$ high to elevate their canopy. Coffee plant pruning's were done according with recommendations set by Fonseca et al. (2017).

Because of the high amount of plants assessed, we grouped coffee plants by sectors A to F, in order to optimize organization, data collection and interpretation. Figure 1 schematizes A to F sectors in the study sites.

Coffee yield (kilograms per coffee shrub) was assessed during four consecutive harvests, from 2014 to 2017. In Brazil, cereja coffee fruits - cereja means cherry in Portuguese - are the berries that are ripe enough to be picked.

We evaluated the coffee productivity of relative to distances between coffee and Ambarella trees in sectors A to F (Fig. 1). We used eight repetitions as seen in Fig. 1, as the defined design repeats itself throughout each crop. The distance between coffee and trees was $1.5 \mathrm{~m}, 4.5 \mathrm{~m}, 7.5 \mathrm{~m}, 10.5 \mathrm{~m}$ and $13.5 \mathrm{~m}$ (sectors A and B); $4.5 \mathrm{~m}, 4.74 \mathrm{~m}, 5.41 \mathrm{~m}, 6.36 \mathrm{~m}$, $7.5 \mathrm{~m}$, and $8.75 \mathrm{~m}$ (sectors $\mathrm{C}$ and $\mathrm{D}$ ); $1.5 \mathrm{~m}, 2.12 \mathrm{~m}, 3.35 \mathrm{~m}$, $4.74 \mathrm{~m}, 6.18 \mathrm{~m}$ and $7.65 \mathrm{~m}$ (sectors $\mathrm{E}$ and F). Average coffee production of the eight repetitions coffee shrubs was calculated with the same distance in N-S and E-W direction. Each plot has around 30 plants. Eight repetitions totaling 240 plants in the N-S

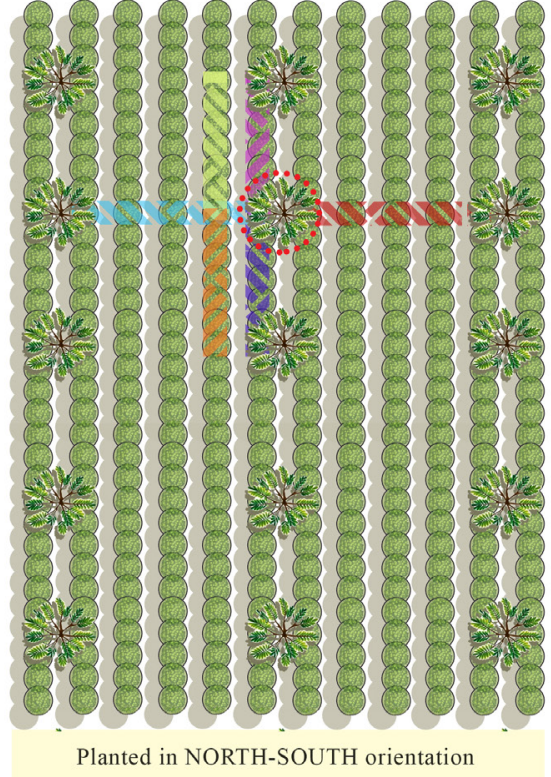

Planted in NORTH-SOUTH orientation
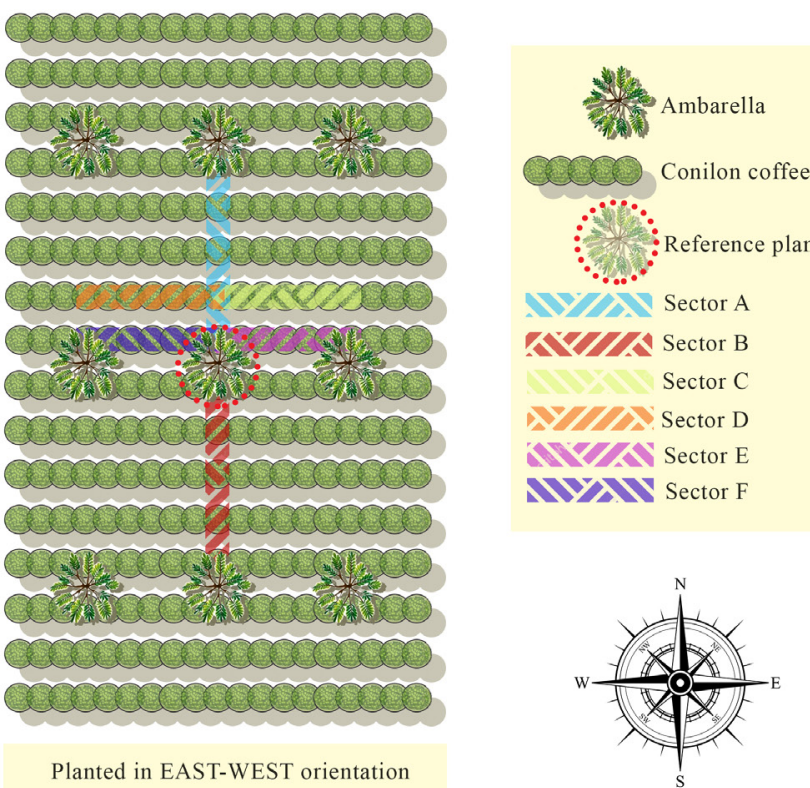

Figure 1: Drawing representing species and sectors $A$ to $F$. 
direction and 240 plants in the W-E direction were evaluated. We used SISVAR, statistical software package (Ferreira 2011) to verify normality to test for differences influenced by distance. A regression analysis of the significant results was tested to verify the influence of Ambarella distance (m) over coffee plants. Regression models were tested by the $\mathrm{F}$ test and regression parameters by the $t$ test. We used Student's t-Test $(p<0.05)$ to test statistical significance between N-S and E-W direction.

\section{RESULTS AND DISCUSSION}

The Fig. 2 shows that the average between coffee crops ranged between $2.177 \mathrm{~kg}$ a $7.346 \mathrm{~kg}_{\text {plant }}{ }^{-1}$. The lowest yield registered on the N-S direction, in 2016 and the highest on the E-W during 2017. Productivity decreased in E-W and N-S orientations $59.3 \%$ and $66.2 \%$ from 2014 to 2016 respectively. At the same time, in 2015 precipitation decreased $57 \%$ relative to the observed average, characterizing an elevated hydric deficit that affected 2015 and 2016 harvests througout the State and region (Camporez 2016).

The N-S harvest had higher productivity during 2014, while in 2015 to $2017 \mathrm{E}-\mathrm{W}$ reached higher average coffee productivity. This variation can be due to the greater shading obtained by coffee plants when placed in a N-S compared to E-W orientation.

In Fig. 3, except for sector $\mathrm{C}$, where coffee productivity adjusted to the regression model and coffee plants established closer to Ambarella produced significantly less, the E-W coffee productivity and Ambarella did not adjust to regression model as a function of distance. This mean that independently from planting spacing, Ambarella had little influence in coffee productivity. Also, N-S productivity did not adjust to regression model, demonstrating that independently of coffee plants position, Ambarella had little effect on coffee productivity. However, in sectors B and E, coffee productivity was influenced by Ambarella (Fig. 4).

From 12 evaluations in the N-S and E-W orientation, we formulated only three equations - two 2nd degree and one of $1 \mathrm{st}$ degree. From these equations, for example, in the N-S direction, B-position, the equation there is a maximum yield point at the distance $\mathrm{x}=7 \mathrm{~m}$, and yield $\mathrm{y}=4.8 \mathrm{~kg} \mathrm{plant}^{-1}$. In this alignment, we recorded increasing productivity from tree 1 at $1.5 \mathrm{~m}$, with $4.04 \mathrm{~kg}$ up to $7 \mathrm{~m}$ with $4.8 \mathrm{~kg}$ plant $^{-1}$ yielding an $18 \%$ increase. At a distance of $13.5 \mathrm{~m}$ from tree 1 , the coffee shrub is $1.5 \mathrm{~m}$ from tree 2 and it had a yield decrease of $28 \%$ at $3.74 \mathrm{~kg} \mathrm{plant}^{-1}$.

Up to the fourth year, we did not find significant effects for either position (N-S and E-W), or competition (water, nutrients and light), relative to distance between coffee shrub and Ambarella.

As in this study, other scholars were able to demonstrate that Conilon coffee can be influenced when intercropped with other species (DaMatta et al. 2017; Coelho et al. 2010; Machado Filho et al. 2009). Intercropping in adequate densities with appropriate species may not affect the development and productivity of coffee plants however, that depends on abiotic conditions of each region such as, soils and climate (Melo; Guimarães 2000; DaMatta 2004; Araújo et al. 2015). In this sense, root distribution across the soil profile is extremely important because tree species with shallow root systems can compete for nutrients and water, limiting the successful intercropping with coffee, mostly in regions prone to long drought periods (DaMatta et al. 2017). In most cases, intercropping coffee with trees species with deep root systems that do not overlap in the soil profile, seems not to compete for water and nutrients with coffee plants (Padovan et al. 2015). In this study, we assume that Ambarella has little interspecific root competition with coffee plants.

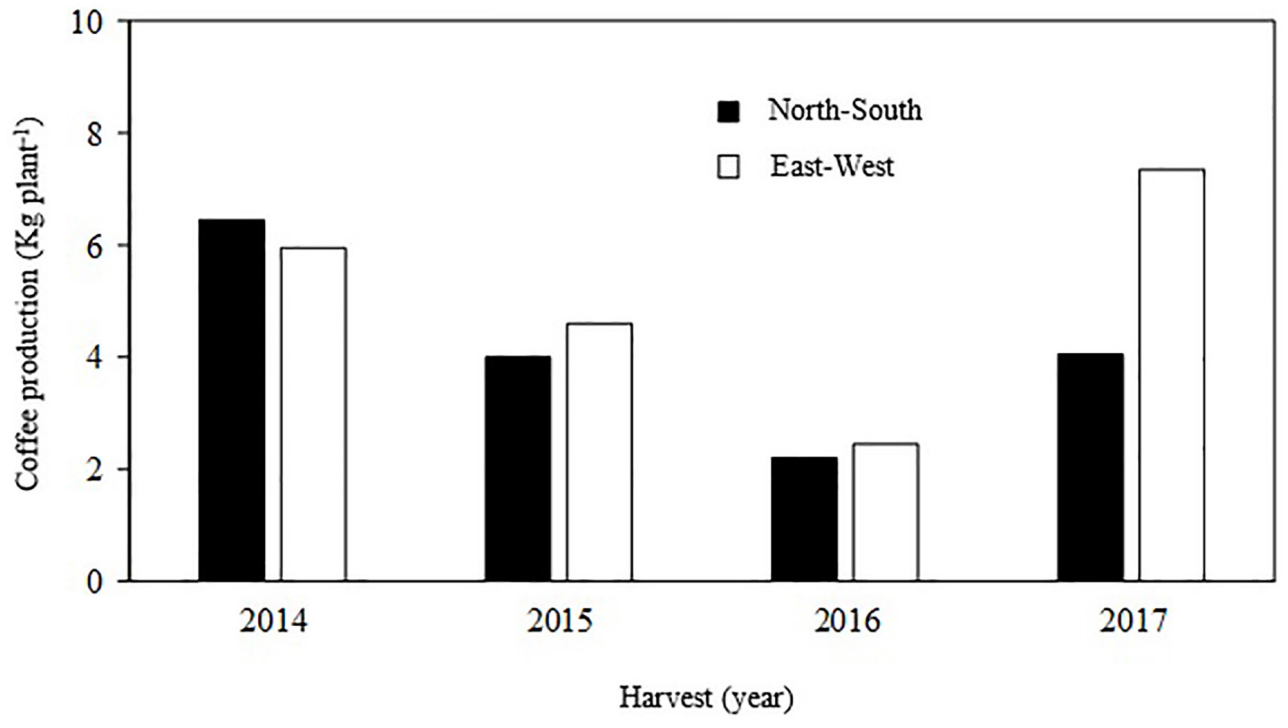

Figure 2: Coffee yield of plants oriented N-S and E-W during 2014 to 2017 harvests. 

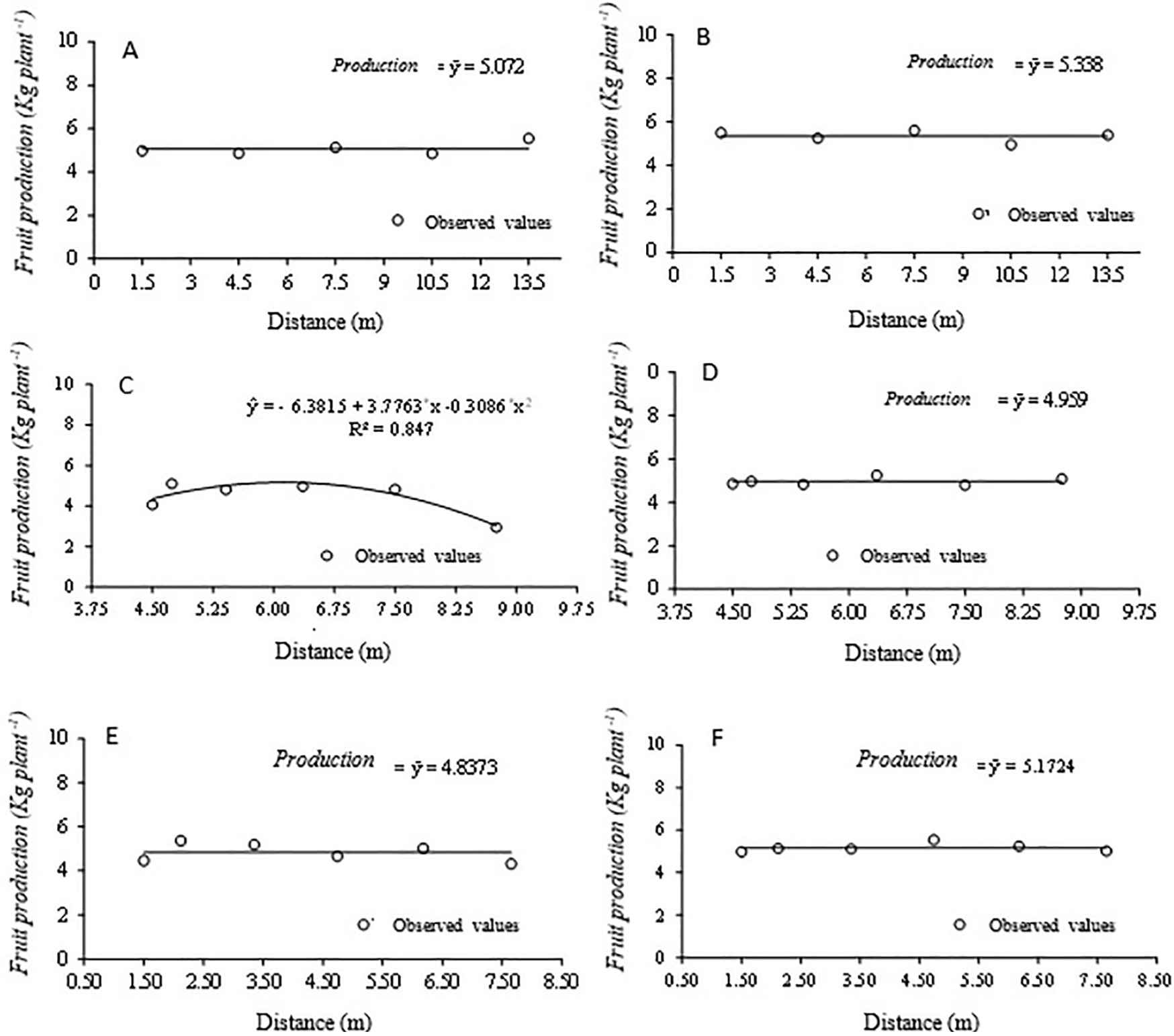

Figure 3: Coffee fruit yield evaluated as a function of the distance of Ambarella, oriented E-W in sectors A, B, C, D, E and F. ${ }^{* *}$, *: significantly different at $1 \%$ and $5 \%$, respectively, according to de Student t- Test.

There are studies that have identified agroforestry systems developed by farmers. For the development of these systems, which tend to be long-lived, the study of farmer initiatives can provide promising indications for improving. There was concordance between technical knowledge and the perception of farmers in relation to the competition about teak and cedar with coffee shrubs. The Jequitibá trees were little influence. On situations of low coffee prices, combined cultivation can guarantee better income (Sales et al. 2013).

In the southern part of State of Bahia and the State of Espirito Santo, Brazil, there are traditional agroforests denominated "cabruca" - a cacao agroecosystem interplanted under thinned - out native forests and the species Spondias mombin L.-, is widely used (Sambuichi et al. 2012). This fruit tree species is of the same genus as Ambarella (Spondias dulcis).

Furthermore, Ambarella is a caducifolious specie, shedding its leaves during wintertime (dry period), permitting greater solar radiation into coffee plants when light span is reduced (Sales et al. 2015). This constitutes a great advantage for coffee plants and an extra benefit from Ambarella plants. 

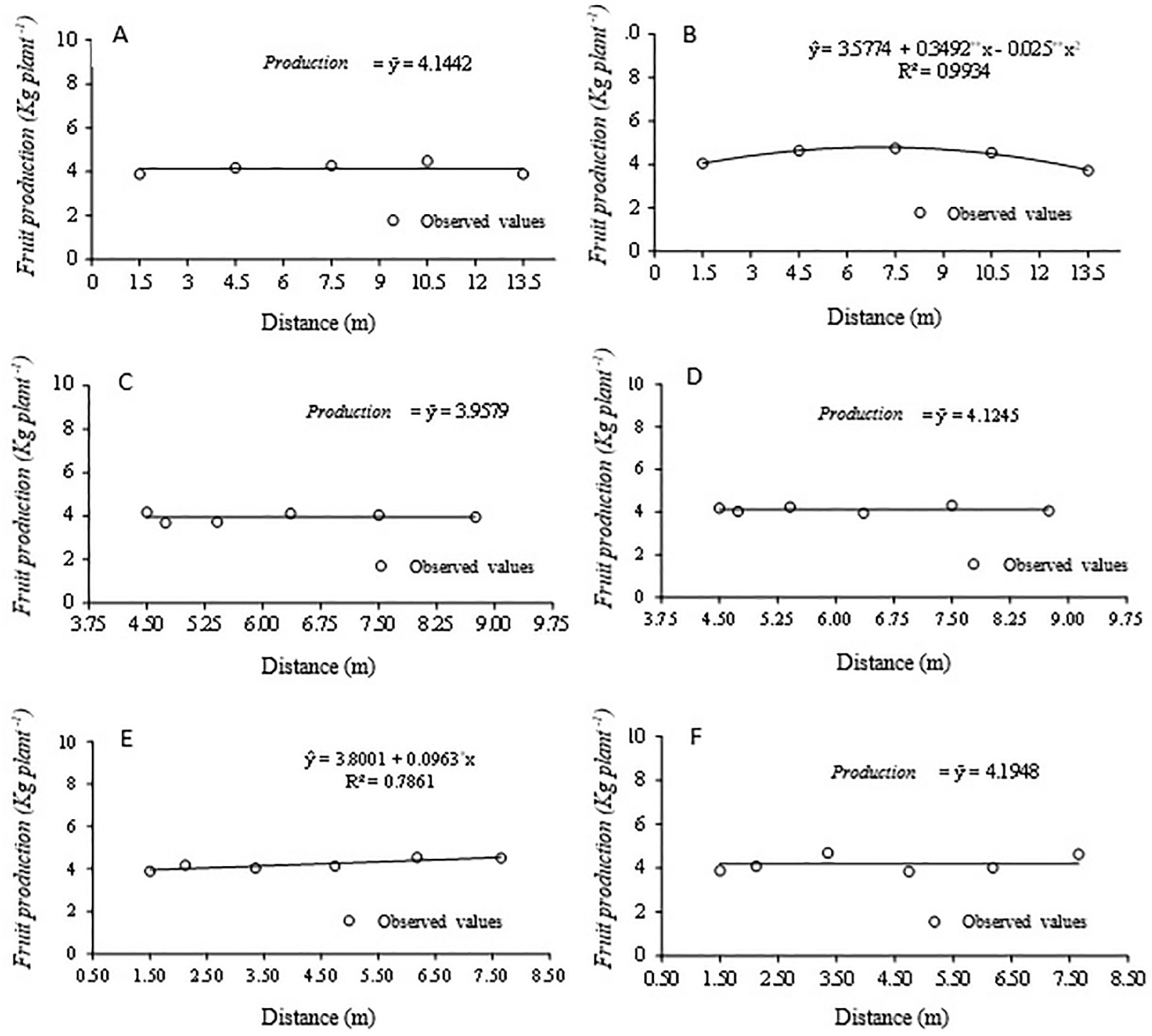

Figure 4: Coffee fruit yield evaluated as a function of the distance of Ambarella, oriented N-S in sectors A, B, C, D, E and F. **, *: significantly different at $1 \%$ and $5 \%$, respectively, according to de Student t- Test.

\section{CONCLUSION}

The average coffee productivity varied from 2.177 to $7.346 \mathrm{~kg}$ plant $^{-1}$, where the lowest productivity was $\mathrm{N}-\mathrm{S}$, registered during 2016, and the highest E-W in 2017. E-W coffee plants also yielded higher productivity compared to N-S from 2015 to 2017. Coffee plants grown in the E-W direction have higher yield compared to the N-S. In general, we did not find that productivity of coffee plants oriented E-W or N-S had any influence due to distance from Ambarella because most sectors did not fit the quadratic regression model. This demonstrates that this tree fruit has little negative influence in coffee productivity and it can be a promising tree species when intercropped with coffee because it can offer an extra income to farmers through the sale of fruits.
We concluded that regardless of planting distance, Ambarella did not significantly affected coffee productivity demonstrating that it can be a fruit tree to intercrop with Conilon coffee, especially in real conditions of coffee grower.

\section{ACKNOWLEDGEMENTS}

We express gratitude to Mr. Doriedson Thomazini, a farmer at Boa Esperança-ES, for graciously welcoming this research in his property. We also thank Espirito Santo Research and Innovation Fund (Fundação de Amparo à Pesquisa e Inovação do Espírito Santo, FAPES) and to the Brazilian Applied Research Corporation - Coffee Consortium, (EMBRAPA - Consórcio Café) for providing research technician funds and technical support funds. 


\section{REFERENCES}

ARAÚJO, A.V. et al. Microclima e crescimento vegetativo do café conilon consorciado com bananeiras. Coffee Science, 10:214, 2015.

CAMPOREZ, P. Seca faz produção cair até $70 \%$ no Espírito Santo. Disponível em: http://g1.globo.com/ espirito-santo/agronegocios/noticia/2016/10/seca-fazproducao-cair-ate-70-no-espirito-santo.html. Acesso em: 03/08/17

\section{CARDOSO, J.H.; et al. Sistemas Agroflorestais e} Conversão Agroecológica: O Desafio do Redesenho dos Sistemas de Produção. Pelotas: Embrapa Clima Temperado, 2013. 29p.

COELHO, R.A. et al. Nível de sombreamento, umidade do solo e morfologia do cafeeiro em sistemas agroflorestais. Revista Ceres, 57(1):95-102, 2010.

COMPANHIA NACIONAL DE ABASTECIMENTO CONAB. Acompanhamento da safra brasileira: Café. V.5 - SAFRA 2018 - N.3 SETEMBRO 2018. Brasília: CONAB, 2018. 77p.

DaMATTA, F. M. Ecophysiological constraints on the production of shaded and unshaded coffee: A review. Field Crops Research, 86:99-114, 2004.

DaMATTA, F. M. et al. O Café Conilon em Sistemas Agroflorestais. In: FERRÃO, R.G.; et al. (Eds). Café conilon. 2. ed. Vitória: Incaper, p. 481-493. 2017.

DIA DE CAMPO. Dia de campo sobre o consorciamento de café conilon e cajá manga. Boa Esperança, 2013. Disponível em: <http://www.es.gov.br/Noticias/159303/ incaperrealiza-dia-de-campo-sobre-consorcio-de-cafeconilon-e-caja-manga-em-boaesperanca.htm>. Acesso em: 03 mar. 2015.

EMPRESA BRASILEIRA DE PESQUISA AGROPECUÁRIA - EMBRAPA. Sistema brasileiro de classificação de solos. 3.ed. Brasília, 2013. 353p.

FERREIRA, D.F. Sisvar: A computer statistical analysis system. Ciência e Agrotecnologia, 35:1039-1042, 2011.

FERREIRA, L.; PINTO, L. S. R C. Estruturados de cajá manga (Spondias dulcis) com diferentes hidrocoloides. ENCICLOPÉDIA BIOSFERA, Centro Científico Conhecer - Goiânia, v.14 n.25; p. 32, 2017.

FONSECA, A. F. A. et al. Manejo da cultura do café conilon: plantio, espaçamento, podas e desbrota. In: FERRÃO, R.G.; et al. (Eds). Café conilon. 2. ed. Vitória: Incaper, p. 275-301. 2017.
GLIESSMAN, S. R. Agroecologia: Processos ecológicos em agricultura sustentável. 2. ed. Porto Alegre: UFRGS, 2001. 653p.

INSTITUTO CAPIXABA DE PESQUISA ASSISTÊNCIA TÉCNICA E EXTENSÃO RURAL - INCAPER. Banco de dados meteorológicos. Vitória, 2017.

IWATA, B. F. et al. Sistemas agroflorestais e seus efeitos sobre os atributos químicos em Argissolo VermelhoAmarelo do Cerrado piauiense. Revista Brasileira de Engenharia Agrícola e Ambiental, 16:730-738, 2012.

MACHADO FILHO, J. A. et al. Avaliação da Produção de Clones de Café Conilon (Coffea canephora cv kouillou) em Consórcio com Seringueira Instalado na Região Nordeste do Espírito Santo. In: Simpósio de Pesquisa dos Cafés do Brasil, 2009, Vitória. Anais do VI Simpósio de Pesquisa dos Cafés do Brasil, Vitória, ES, Brasil. Brasília: Embrapa Café, 2009. 6p.

LORENZI, H. et al. Frutas brasileiras e exóticas cultivadas. Nova Odessa: Instituto Plantarum de Estudos da Flora, 2006, 640p.

MELO, J. T.; GUIMARÃES, D. P. A cultura do café em sistemas consorciados na região do Cerrado. In: I Simpósio de Pesquisa dos Cafés do Brasil. Poços de Caldas. Resumos expandidos. Embrapa. p. 963-966, 2000 .

NÓBREGA, N. E. F. et al. Balanço hídrico climatológico e classificação climática de Thornthwaite e Köppen para o município de Boa Esperança-ES. In: congresso nacional de irrigação e drenagem, 18., 2008, São Mateus. Anais... São Mateus: ABID, 2008

PADOVAN, M. P. et al. Root distribution and water use in coffee shaded with Tabebuia rosea Bertol. And Simarouba glauca DC. Compared to full sun coffee in sub-optimal environmental conditions. Agroforestry Systems, $89: 857-868,2015$.

PERFECTO, I. et al. Biodiversity, yield, and shade coffee certification. Ecological Economics, 54(4):435-446, 2005.

PREZOTTI, L. C. et al. Calagem e adubação do Café Conilon. In: FERRÃO, R. G. et al. Café conilon. 2.ed. Vitória: INCAPER, p. 347-357, 2017.

SALES, E. F. et al. Agroecological Transition of Conilon Coffee (Coffea canephora) Agroforestry Systems in the State of Espírito Santo, Brazil. Agroecology and Sustainable Food Systems, 37:405-429, 2013. 
SALES, E. F.; et al. Cafezais associados ao cajámanga (Spondias dulcis Parkinson) no estado do Espírito Santo. In: IX Congresso Brasileiro de Agroecologia, 2015, Belém. IX Congresso Brasileiro de Agroecologia IV Seminário Estadual de Agroecologia, 2015, Cadernos de Agroecologia. Vol $10, \mathrm{~N}^{\mathrm{o}} 3$.

SAMBUICHI, R.H.R. et al. Cabruca agroforests in Southern Bahia, Brazil: tree components, management practices and tree species conservation. Biodiversity and Conservation. (21): 1055-1077, 2012 .
SILVA, G. A. et al. Gênero Spondias: Aspectos botânicos, composição química e potencial farmacológico. BioFar, 10(1), 2014.

SOUZA, C. A. S. et al. Comportamento de clones de Coffea canephora Pierre ex Froenher sombreados com boleira (Joanesia princeps Vell.) e cajazeira (Spondia dulcis Forst.), no norte do Espírito Santo. In: SIMPÓSIO DE PESQUISA DOS CAFÉS DO BRASIL, 4., 2005, Londrina. Anais... Brasília: Embrapa Café, 2005.

TEIXEIRA, A. F. R. et al. Fauna edáfica em sistemas arborizados de café conilon em solo de tabuleiros costeiros. Coffee Science, 9(3):385-393, 2014. 